\title{
Influential Factors on Profitability of Islamic Banks: Evidence from Sudan
}

\author{
Ahmed Nourrein Ahmed Mennawi ${ }^{1} \&$ Ahmed Ali Ahmed ${ }^{1}$ \\ ${ }^{1}$ College of Business Studies, Sudan University of Science and Technology, Khartoum, Sudan \\ Correspondence: Ahmed Nourrein Ahmed Mennawi, College of Business Studies, Sudan University of Science \\ and Technology, Khartoum, Sudan. Tel: 249-912-155-537. E-mail: ahmednourrein@ gmail.com
}

Received: March 12, 2020

Accepted: April 12, 2020

Online Published: May 5, 2020

doi:10.5539/ijef.v12n6p1

URL: https://doi.org/10.5539/ijef.v12n6p1

\begin{abstract}
Profitability of Islamic banks has a significant effect on banks current and future decisions that do not only associate with shareholders and management, but also for various types of stakeholders. Despite that, scholars are not yet in agreement on common determinants of profitability in banking industry. This study aims to investigate the effect of bank-specific and industry characteristics along with macroeconomic variable (the inflation) on the profitability of a sample of 10 Islamic banks in Sudan. The study applied descriptive statistics, Persons' correlation and multiple regression analysis on secondary data in order to determine the relationships and degree of significant of the independent variables to profitability. The profitability has been measured by two models; as return on assets (ROA) and net profit margin (NMP). The results reveal that bank capitalization (EQTA), operational cost efficiency (OCOI), investment in short-term securities (SECA) and inflation (INF) variables are significantly affecting the profitability of Islamic banks in Sudan. In contrary, the deposit-size of the bank (as market share) is not a significant determinant of banks' profitability. Furthermore, the results indicate that quality of credit loan (NPL) is highly significant to NPM, while it is insignificant to ROA.
\end{abstract}

Keywords: Islamic banks, profitability, capitalization, Sudan, microeconomic factors, short-term securities

\section{Introduction}

\subsection{Islamic Banking Overview}

Islamic banking industry reach a maturity level at the present since it has been launched in its modern phase five decades ago. This banking system follows Shariah guidelines that based on profit-sharing, instead of interest charge on financing. In addition to that Islamic banks have a mandate to undertake direct investments and participate in the management of financed projects. However, the equity financing - that features in Islamic banking - is much risky because the Islamic banks shoulder the losses from the project along with the investor (Brown, Hassan, \& Skully, 2007). The assets size of Islamic finance industry is expected to reach US\$3.81 trillion by 2023. Given that, Iran, Saudi Arabia and Malaysia are the largest Islamic markets with a share of $65 \%$ of the Islamic assets (US\$ 2.44 trillion) by 2017, while Malaysia, Bahrain and the UAE led the Islamic economics in terms of product development. It is worth to note that, Islamic banking accounted for almost $70 \%$ of assets in the Islamic finance industry during the period 2017/2018, while the industry has a substantial growth with 6\% of the compound annual growth rate during 2012-2017 (Thomson Reuters, 2018). Despite of the fastest growing of Islamic banking sectors, it is still relatively small compared to the global industry. However, there is an expectation indicates that the Islamic banking will be significantly grow at a healthy pace as many Muslims interested in considering Islamic finance and non-Muslims looking to diversify their choices and to fulfil their ethical values (Abdullah \& Chee, 2014).

The banking sector in Sudan - as most in other Islamic countries - plays a vital role for promoting the various commercial and non-commercial sectors throughout Islamic financing modes that create a development in overall economy. Introduction of Islamic banking in Sudan began on 1984 and it passed through different stages till reaching to a full-fledged Islamic financial system in 1992. Sudan became one of a few countries in the world that has a fully-fledge Islamic financial system. Currently, the banking system consists of Central Bank of Sudan (CBOS) as regulatory body and 37 banks that divided into state-owned banks, jointly-owned banks, and branches of foreign banks. Adding to this, Shariah Supervisory Board as part of supervisory and the Banking Deposits Guarantee Fund. Despite of experiencing remarkable growth in recent, the financial system in Sudan 
remains small relative to its regional peers; as intermediation is low, the equity and foreign exchange markets are narrow, and non-banking financial markets and institutions are small and yet developing (Burger, 2018).

\subsection{The Significant of Study}

The importance of the study comes from the different dimensions. Islamic Bank's profitability is a paramount important matter for Sudanese banks, especially during the recent challenges that imposed by political changes, macroeconomics factors and technology development. Shareholders are usually keen to assure that their value is maximized without having the bank to rely on equity to compensate the depositors' risk, CBOS emphasizes on the stability and soundness of banking system for the benefits of country economy and social commitments, depositors are closely monitoring their funds to assure their safety, investment accounts holders aim to achieve their targeted profits with affordable risk, and bank's management is looking forward to promote the banks financial capacity.

\subsection{The Statement of Problem}

The statement of problem being articulated as the lack of identifying, assessing and managing the determinants of bank's profitability has a potential adverse impact on bank's strategic position and country economy, as well as different stakeholders. Moreover, current and potential investors are keen to understand and analyse the profitability of banks in order to assess their investment opportunities and make rational decisions. Furthermore, a comprehensive investigation of the profitability of Islamic banks in Sudan during the period of 2009 to 2018 is essential in this study.

\subsection{The Objectives, Scope and limitation of the Study}

The primary objectives of this study are to empirically investigate and assess the factors that are influencing the Islamic bank profitability in Sudan, and to highlight key facts pertaining banking performance which can assist both decision and policy makers in banking industry. Moreover, the study aims to contribute to the Islamic banking literature as a way forward to enrich the empirical studies area.

The study has been designed as follows: Section two provides a brief literature that focuses on profitability determinants in banking industry, which takes different style of studies. Section three demonstrates the study methodology, variables characteristics and analysed data. Section four tackles the study results and discussion on the analysis findings. At last, section five summarized the study by a conclusion and highlights some recommendations. We clearly identify that the study limitations lie on the study period that covers only 10 years (2009-2018), and the lack of available data from all banks that operate in Sudan; therefore, our sample is limited to 10 Islamic banks.

\section{Literature Review}

There are many relevant related studies that conducted in the area of profitability determinists in Islamic banks. This study organised the relevant literature into three categories. First category includes the studies that cover the profitability and its determinants in either Islamic or conventional banks in a single country, followed by the second category that tackled some of cross-country studies for the same subject. The third category includes the studies that conducted to compare the profitability determinants between Islamic and conventional banks.

\subsection{Studies of Country Cases}

Dietricha and Wanzenried (2009) examined the impact of bank-specific characteristics, macroeconomic variables and industry-specific factors on the profitability of banks in Switzerland. The authors used a linear regression model to assess the sample of 453 banks during the period of 1999 to 2006. Profitability of banks measured by the return on average assets (ROAA). The study found that capital ratio (equity over total assets) and GDP have a positive and significant impact on bank profitability. The bank efficiency that measured by cost to revenue ratio found to be highly significant and negative to the profitability while the credit quality (loan loss provisions to loan) and annual deposits growth have insignificant impact. Moreover, the study provided an evidence that privately-owned banks are more profitable than state-owned banks in Switzerland. In addition to that the taxation has small negatively impact on bank profitability as banks seem to be able to shift a large portion of their tax charges towards depositors and borrowers.

Using a sample of 6 Islamic banks in Pakistan during 2006-2009, Akhtar, Ali, and Sadaqat (2011) investigated the impact of bank specific factors on profitability which measured by Return of Assets (ROA) and Return on Equity (ROE). The authors applied ordinary least square method to analyse the variables. The study revealed that gearing ratio and capital adequacy ratio found to have a positive relation and statistically significant to profitability, whereas the asset management (Operating Income/Total Assets) is statistically insignificant to ROA 
and significant to ROE with positive relation in both models. Another result identified by the study is that the credit quality (NPLs) ratio has a negative relationship and significant to ROA while the bank's size reported negative and insignificant relation in both models.

Tan and Floros (2012) assessment of ROA and NIM (Net interest income/earning assets) on a sample of 101 Chinese banks over the period 2003-2009. The authors used unbalanced panel estimation. The study revealed that cost efficiency, labour productivity and inflation are significant and positively related to profitability. While the credit risk, fee-based activity and concentration have a negative and significant impact to bank's profitability. Moreover, the results indicated that there is a positive relationship between bank profitability and both banking sector development and stock market development in China

In a study of 17 Islamic banks in Malaysia, Muda, Shaharuddin, and Embaya (2013) have conducted a comparison of profitability determinants of the domestic and foreign Islamic banks. The study applied unbalanced panel data with Generalized Least Square model, using quarterly data for the period of 2007 to 2010. The study found that equity to total assets, bank age and inflation rate have a negative and statistically significant impact on the ROE of both domestic and foreign banks; while the liquidity ratio (LATA) has insignificant impact on the profitability for both type of banks. In addition to that technical efficiency and bank size (Log. Assets) have a positive and statistically significant impact on the ROE of domestic banks, in contrast, they appeared to have and positive insignificant impact on the ROE of Foreign banks. The findings also indicated that the global financial crisis affected the profitability of domestic banks sampled only.

In study conducted to investigate the relationship of credit risk and operational efficiency to the banking profitability, Buchory (2015) selected a sample of 26 regional development banks in Indonesia. The authors applied the multiple linear regression for the secondary data that collected from a quarterly report for the year 2014. Credit risk measured by non-performing loans (NPLs), operational efficiency measured by ratio of operating expense to operating income (OEOI) and banking profitability measured by return on assets (ROA). Results revealed that NPLs has positive and significant effect to ROA, while the OEOI has negative and significant effects to the ROA

Aslam, Inamullah, and Ismail (2016) tested the main factors that affect the profitability of Islamic bank in Pakistan for the period of 2007 to 2014. Data collected from the quarterly reports of 5 full-fledged Islamic banks and 17 conventional banks. The authors used multiple regression analysis for testing the data. The study found that bank-size, deposits, financing, market share, GDP and Inflation have insignificant to profitability measures ROA and ROE. However, Size, financing and market share showed a positive sign over ROA and ROE whereas Deposits, GDP and Inflation have an adverse direction to ROA and ROE.

Mehta, and Bhavani (2017) conducted a study that investigated the impact of bank-specific, macroeconomic, and industry-specific factors on the profitability of 19 UAE domestic banks. The authors used the panel data regression to analyse a secondary data over 8 years (2006-2013). The empirical results indicated that the cost efficiency, capital adequacy ratio, and asset quality were the most significant variables that could impact the banks' profitability. The loan loss provision and cost to income ratio found to be significantly negative on all measures of profitability in this study. Moreover, the economic indicators provided no impact on the NIM while the GDP has a positive and significant influence to ROA. The study remarked that the enhancement of banks profitability can take place by diversifying the source of revenue with non-interest-based sources, although it provides a negative impact on the NIM.

Another study that done by Jamel and Mansour (2018), authors examined the bank-specific, regulatory policies and macroeconomic variables on the performance measures of Tunisian banks. The authors measured the banks' profitability by ROA and NIM and they used GLS to estimate the panel data that collected from 11 listed Tunisian banks during the period of 1999-2016. The study found that the equity and size of bank factors have a positive and significant impact on both models of ROA and NIM, while the credit risk showed a significant impact with inverse sign to ROA and positive indicator to NIM. Moreover, the financial regulation (reserves requirement) and crisis seems has a positive and significant impact on ROA of the selected ample, whereas they seem to have no impact on NIM measure of profitability. The results revealed that GDP and market capitalization have no effect to the profitability measures, while the inflation has a positive and significant impact on NIM and no impact on ROA. The authors claimed that the improvement of performance by Tunisian banks largely reflects the prudential supervision that exercised by the Central Bank.

Concerning Islamic banks in Sudn, Elgadi and Yu (2018) investigated the profitability determinants in a sample of 27 banks from 2005 and 2013. The results showed that ownership, capitalization (Total Equity to Total Assets) and asset utilization (Operating Income to Total Assets) have a positive and significant impact on profitability 
measure (ROA) while operation efficiency (Total Cost to Total Income), bank age, leverage (Total Liability to Total assets) and specialization have an adverse impact. Furthermore, the study revealed that the credit risk, liquidity risk, overhead expenses to total expenses ratio and size of the bank have no impact on profitability measure (ROA and ROE). The empirical evidences have indicated that the Profit and Loss Sharing (PLS) mode of finance seems to be positively affecting the banks financial performance (ROA and ROE). The study also indicated that privately owned banks show a higher profitability than state owned banks.

Hassan and Ahmed (2019) applied the panel analysis (fixed effects model) to examines the impact of bank specific characteristics in determining the profitability of all Islamic banks in Bangladesh during 2010 to 2017. Bank profitability measured by ROA and bank explanatory variables included the size, capital to risk assets, liquidity risk (investment to deposit), credit risk (non-performing investment), and operational efficiency (cost to income). The study results repealed that bank-size, capital and cost to income have a negative correlation and significant; while liquidity and credit risk are significant and positively correlated to bank profitability.

\subsection{Comparative Studies of Islamic vs Conventional Banks Profitability}

Shams, Jan, Iqbal, and Ali (2012) have collected data from 6 Islamic banks and 20 conventional banks in Pakistan to study and compare the profitability determinants. The authors used multi-variant regression model on the pooled samples and data covers the period from 2006 to 2010. The study found that bank-size has a negative correlation and significant to bank profitability (ROA), while the bank-capital and deposit to asset ratios indicated a positive and significant impact to ROA. The results supported the author in remarking that. Another study conducted by Rashwan and Ehab (2016) to evaluate the efficiency of performance of Islamic and traditional banks in 12 countries within a sample of 66 banks and throughout the period from 2009 to 2014. The author used the financial ration, One-way ANOVA and multiple regression analysis to generate the research findings. The efficiency of the performance of the banks measured by ROA and ROE. The research found that the traditional banks is superior in terms of cost, revenue and profit efficiencies in a comparison with Islamic banks. Furthermore, the results revealed that the efficiency of Islamic banks has more influence on their profitability compared to their traditional counterparts. Moreover, Inflation factor showed a minimal impact on the efficiency of both banking systems.

\subsection{Banks Profitability in Cross Country Studies}

Bashir (2003) analysed how bank characteristics and financial environment affect the Islamic banks performance that measured by ROA and ROE. The sample covered banks in 8 Middle Eastern countries for the period from 1993 and 1998. The results indicated that high capital-to-asset and loan-to-asset ratios have a positive response and significant affect for increasing the Islamic banking profitability. This results match with Hassan and Bashir (2005) findings in a study that covered Islamic banks in 21 countries during 1994-2001. Bashir (2003) found that the foreign-owned banks are likely to be profitable. Also, an adverse impact of taxes on bank performance and profitability has been noted by the author while higher GDP per capita and higher inflation rates reflected a strong positive influence to the performance measures. The study strongly remarked that adequate capital ratios and loan portfolios have a critical role in explaining the performance of Islamic banks. Furthermore, Haron and Azmi (2004) used a pooled time-series and cross-sectional data that taken from the from 5 countries during 1984-2020 to examine the factors that determine the profitability of Islamic banks. Their study found a significant positive relationship between profitability measures and independent variables that include liquidity (financing to deposits), deposit, and inflation. While, both the assets structure that measured by total funds in PLS to total assets and money supply indicated as significant explanatories but with inverse relationship with profitability. Finally, the market share and bank size have been found not to have any significant relationship with Islamic banks' profitability. Another study examined the performance and efficiency indicators of Islamic banks worldwide was conducted by Hassan and Bashir (2005) argued that Islamic Banks' loans are low risk and only contribute modestly to the profitability. The authors indicated that short-term funding, non-interest earning assets, and overhead are important factors in promoting banks' profits. Oino (2015) investigated how competitive the banks in sub-Saharan Africa are and what determines their profitability. They used a panel data of 97 sub-Saharan African banks for the period from 2000 to 2012. Their study revealed that the cost to income ratio and capital ratio are negatively and significantly influence profitability. Moreover, GDP, inflation and interest have an impact on the performance of the bank. The study remarked that the more diversified resources support the bank in generating profit. Furthermore, Aliyu and Yusof (2016) investigated the significant elements that predict profitability (ROA) of Islamic banks within the composition of cost efficiency (non-interest expenses to average asset), capitalization (equity to the total asset), liquidity ratio (net interest revenue/income to the average asset) macro factors that include inflation, GDP and exchange rate. Their study revealed to find that capitalization ratio, cost efficiency, operating income, revenue gain, other securities, and macroeconomic 
variables explain the behavior of profitability performance in the banks sampled. The study argued that cost efficiency is an important factor in determining the resources utilization and achieving high returns infavour to banks' stakeholders.

\section{The Dataset and Methodology}

\subsection{The Objective and Analysis Method}

The objective of this study is to empirically investigate the impact of the bank-specific, industry and macroeconomic determinants on banks' profitability in Sudan. The study selected six (6) independent variables in reference to the previous literature that tested similar variables in different cases and countries. The profitability of banks has been measured by the ratios of return on assets and operational profit margin. We used IBM SPSS 25.0 software to analyse the secondary data throughout the descriptive statistics, Pearson correlation and multiple regression analysis. Regression analysis proved to be one of the suitable methods that provides prediction and explanation the magnitude of independent variables to dependent one. This method has been used in previous studies for Dietricha and Wanzenried (2009), Buchory (2015), Aslam and Inamullah (2016), and Rashwan and Ehab (2016)

\subsection{Study Data, Sample and Hypotheses}

\subsubsection{The Data and Sample}

The study data has been compiled from the annual financial reports of 10 commercial banks and from the Central bank of Sudan statistical reports for a period of 10 years (2009-2018). Given that, the study analysed a number of 100 observations that provide a statistical power of the significance testing of the results throughout multiple regression method (Hair, Black, Babin, \& Anderson, 2014). The banks sampled in this study represent $27 \%$ from total banks (37 banks) that operate in Sudan at time of the study. The selection of the sample based on the availability of data that can be accessed to cover the period of this study.

3.2.2 The Study Hypotheses

Following null hypotheses (H0) have been tested with confidence level of $95 \%(\alpha=0.05)$ :

1). The bank's capitalization has a positive and significant impact on profitability of banks in Sudan.

2). The operational cost efficiency has a negative and significant impact on profitability of banks in Sudan.

3). Investment in short-term securities has a positive and significant impact on profitability of banks in Sudan.

4). The credit risk has a negative and significant impact on profitability of banks in Sudan.

5). The increase in bank's market share has a positive and significant impact on profitability of banks in Sudan.

6). The increase in inflation rate has a positive and significant impact on profitability of banks in Sudan.

\subsection{Characteristics of Variables}

To investigate the bank profitability, the study selected the independent variables from three categories. These are: bank-specific (internal) variables, industry based, and macroeconomic variables.

\subsubsection{Profitability Measures}

The independent variable in this study is the profitability of Islamic banks in Sudan. The literature provides an evidence that most common measures for the bank's profitability include Return of Assets (ROA), Return of Equity (ROE), and/or Net Interest Margin (NIM). Since the Islamic banking does not deal with interest, the ratio of Net Interest Margin (NIM) is not applicable. Accordingly, some authors modified it to Non-Interest Margin. The ROA used by Dietricha and Wanzenried (2009), Buchory (2015), and Hassan and Ahmed (2019), while the ROE applied in the study that conducted by Muda et al. (2013). Furthermore, profitability measured by two models that include ROA \& ROE used in the studies of Bashir (2003), Akhtar et al. (2011), Oino (2015), Aliyu and Yusof (2016), Aslam et al. (2016), Rashwan and Ehab (2016), and Elgadi and Yu (2018). Moreover, the ratios of ROA\& NIM used by Tan and Floros (2012). In addition to that, multiple measures for bank's profitability found in Mehta and Bhavani (2017) study in term of ROA, ROE and NIM; while ROA, ROE, Non-Interest Margin and Profit Margin ratios applied by Hassan and Bashir (2005).

This study identified the Retune on Assets (ROA) and Net Profit Margin (NPM) as proxies for profitability of banks since both ratios summarize the profitability and efficiency of the banks.

\subsubsection{Return on Assets (ROA)}

Return on Assets (ROA) explains the bank's profitability, efficiency of managing the resources and financial 
performance of the bank. It shows the performance result in allocating overall company's resources into net profit during the financial period. ROA is calculated by dividing net profit by total assets in order to determine how much profit earned per unit of assets. The higher ROA the better indication of a bank's profitability and financial performance.

\subsubsection{Net Profit Margin (NPM)}

Net profit margin represents the net profit (after tax) over the annual revenue that generated by the bank. It is a good indicator to assess the operational efficiency that reflected into bank's assets management. NPM is calculated by dividing the net profit to the revenue for a given period, which is a year in this study.

\subsubsection{Bank Capitalization (Equity to Assets - EQTA)}

The EQAS refers to the total assets that financed by shareholders equity. It also considers as an indicator for bank's capital adequacy to explain the bank ability to absorb losses and manage the risk exposure with shareholders. The increase in capitalization ratio comes from a number of factors that includes better profitability and new injections of capital (Siddiqui, 2008). The bank capitalization in this study is calculated by dividing the total shareholders equity to total assets. The higher EQTA ratio leads to low insolvency profile and more profitability. This measure has been used as independent variable in many studies by Bashir (2003) Dietricha and Wanzenried (2009), Muda et al. (2013), Elgadi and Yu (2018), Jamel and Mansour (2018), Hassan and Bashir (2005), Oino (2015) and Aliyu and Yusof (2016).

\subsubsection{Operational Cost Efficiency: (OCOI)}

The operational cost over income is commonly used as a metric for the bank's operational efficiency. At the decrease of OCOI ratio, the bank efficiency improves and consequently contributing positively to its profitability. Operational efficiency used as profitability determinant by many authors such Dietricha and Wanzenried (2009), Tan and Floros (2012), Buchory (2015), Rashwan and Ehab (2016), Elgadi and Yu (2018), Mehta and Bhavani (2017), Hassan and Ahmed (2019), and Oino (2015).

\subsubsection{Investment in Short-term Security (SECA)}

We believe that on there is almost an absence of interbank market in Sudan, therefore most of banks are boosting their liquidity management by maintaining short-term securities that are Shariah compatible, which called Sukuks. Such Sukuks provide not only a liquidity management tool but also, they become a persistent source of profit. Furthermore, Central bank of Sudan allows the banks to maintain no more than $25 \%$ from their liquidity base in the form of Ijara and Musharakah Sukuks (CBOS, 2011). Generally, the SECA is calculated by total short-term securities divided by total assets. SECA ratio explains how much its portion from overall bank's balance sheet size. We assume that the higher SECA indicates more profitability of bank.

\subsubsection{Quality of Credit (Non-performing Loan "Financing" - NPL)}

The literature shows that NPL ratio is an indicator for quality of credit or bank financing. It measures the percentage of gross loans (financing) that are in doubtful or impaired in bank's portfolio of investment. The lower the NPL ratio, the better the quality of credit and the more profit in bank. NPL appeared as independent variable in the studies that conducted by Akhtar et al. (2011), Tan. and Floros (2012), Buchory (2015), Hassan and Ahmed (2019) and Oino (2015).

\subsubsection{Market Share (MRKD)}

Market share is one of the industry factors that expected to have an influence to bank's profitability. Since there are many elements that can be used to measure the portion of the bank in the market, we used the customers' deposits as the bank primarily utilizes them to generate profit. The author calculated MARD ratio as a percentage of the bank's deposits to overall market's total deposits. The study assumes that an increase of bank's market share leads to increase the profitability. Market share as independent variable applied in the studies of Haron and Azmi (2004), and Aslam et al. (2016).

\subsubsection{Inflation Rate (INF)}

Inflation rate is a macroeconomic variable that refers to a sustained increase in the price level or the Consumer Price Index (CPI). It seems to be harder to predict the inflation impact on bank's profitability in Sudan specially the average annual inflation rates vary during the period of the study, and banks status in liquidity and investment portfolios are differ, too. Furthermore, it's clearly that Sudan is facing a rapidly increase in the inflation rates that can not be avoided by all industries, including the banking sector. The impact on bank's profitability it depends on whether bank can be able to increase its products' prices or transferring the rising costs to their customers. We assume that the banks can be able to transfer the rising costs to their customers and 
reduce the real value of customers' deposits, which lead to improve their profitability. Given that, inflation rate causes an increase in profitability of banks. In previous studies, the inflation rate has been used by Bashir (2003), Haron and Azmi (2004), Hassan and Bashir (2005), Tan and Floros (2012), Muda et al. (2013), Oino (2015), Aliyu and Yusof (2016), Aslam et al. (2016), Rashwan and Ehab (2016), and Jamel and Mansour (2018).

Table 2 gives a summary of the study's variables:

Table 1. The dependent and independents variables

\begin{tabular}{llllc}
\hline Variable & Symbol & Proxies & Type of Variable & Expected Sign \\
\hline Return on Assets & ROQ & Net Profit / Total Assets & Dependent & NA \\
Net Profit Margin & NPM & Net Profit / Income & Dependent & NA \\
Bank Capitalization & EQTA & Total Equity / Total Assets & Independent & + \\
Operational Cost Efficiency & OCOI & Operating Cost/Operating Income & Independent & - \\
Investment: Shortterm Security & SECA & Shor-term Securities/Total Assets & Independent & + \\
Quality of Credit & NPL & Nonperforming Loan/Gross Financing & Independent & - \\
Market Share & MRKD & Bank's Deposits / Total Banks Deposits & Independent & + \\
Average Inflation & INF & Average Annual Inflation Rate & Independent & + \\
\hline
\end{tabular}

Source: Researchers' outputs.

\subsection{Model Specification}

The model has been formulated as follows:

$$
\begin{aligned}
& \text { Model 1: } \mathrm{ROA}=a+\beta 1 \mathrm{EQTAit}+\beta 2 \mathrm{OCOIit}+\beta 3 \mathrm{SECAit}+\beta 4 \mathrm{NPLit}+\beta 5 \mathrm{MARKDit}+\beta 6 \mathrm{INFit}+\varepsilon \\
& \text { Model 2: NPM }=a+\beta 1 \mathrm{EQTA} \text { it }+\beta 2 \mathrm{OCOIit}+\beta 3 \mathrm{SECAit}+\beta 4 \mathrm{NPLit}+\beta 5 \mathrm{MARKDit}+\beta 6 \mathrm{INFit}+\varepsilon
\end{aligned}
$$

Whereas:

a: the intercept;

$\beta 1, \ldots, \beta 6$ : the regression coefficient of independent variables.

$i \& t$ : they refer to the banks and the period in the study, respectively.

$\varepsilon$ : prediction error (residual).

\section{Empirical Analysis, Results and Discussion}

\subsection{Descriptive Statistics}

Descriptive statistics are summarized in table (2), in order to shed a light on the basic features of data in the study. The table 2, provides the descriptive values in the form of maximum, minimum, mean, standard deviation (SD), skewness and kurtosis for the dependent variables and independent variables during the period 2009 to 2018. The descriptive statistics indicate that all variables are associated with positive mean values while their standard deviations are varied. The averages of profitability measures of ROA and NPM in the banks sampled are 2.74 and 34.56, respectively. Moreover, the standard deviation for both ROA and MRKD (SD $=2.597 \&$ SD $=5.4999$, respectively) show relatively high variation to their mean values. We can see that $95 \%$ of ROA falls between -2.45 and 7.93 , while the NPM ranges from -7.74 to 76.86 at the same level of confidence. The descriptive statistics reveals that part of the banks within the sample faced significant losses that lead to bring negative EQTA ratio (min of -1.65) while other achieved considerable capitalization ratio (max of 63.23), with an overall average of $17.35 \%$ ( $\mathrm{SD}=12.59$ ). Table 2 , also suggests that operational cost efficiency (OCOI) for the banks in Sudan is vary between $23.07 \%$ to $290.04 \%$, with a mean of $65.09 \%$ ( $\mathrm{SD}=31.31$ ).

The average investment in short-term securities to banks' total assets during the study's period is $15.4 \%$ (SD = 13.04). In addition to that the sample consists of different sized banks, as their market shares vary from $0.12 \%$ to $24.59 \%$ with mean equal to $4.66 \%$ ( $\mathrm{SD}=5.5$ ). Considering the general acceptable values for asymmetry and kurtosis between -2 and +2 to prove the normality of distribution, the exceptions come from dataset of OCOI and SECA that seems to be highly skewed positively, and the kurtosis values for ROA, NPM, OCOI and SECA that indicate a significant departure from normality. Otherwise, most of datasets follow the normality. 
Table 2. Summary of descriptive statistics

\begin{tabular}{llcccccc}
\hline Variable & & Min & Max & Mean & SD & Skewness & Kurtosis \\
\hline Dependent & ROA & -7.02 & 15.99 & 2.7403 & 2.5969 & 1.104 & 7.846 \\
Dependent & NPM & 0.83 & 137.01 & 34.5594 & 21.1497 & 1.106 & 4.039 \\
Independent & EQTA & -1.65 & 63.23 & 17.3455 & 12.5907 & 1.383 & 1.295 \\
Independent & OCOI & 23.07 & 290.04 & 65.0901 & 31.3086 & 3.881 & 26.148 \\
Independent & SECA & 0.03 & 71.34 & 15.3976 & 13.0373 & 2.085 & 5.379 \\
Independent & NPL & 0.50 & 22.38 & 6.2219 & 4.3010 & 1.155 & 1.524 \\
Independent & MRKD & 0.12 & 24.59 & 4.6628 & 5.4999 & 1.681 & 1.885 \\
Independent & INF & 12.61 & 72.93 & 30.0877 & 17.8384 & 1.244 & 0.791 \\
& Valid N & 100 & 100 & 100 & 100 & 100 & 100 \\
\hline
\end{tabular}

Note. Min: Minimum, Max: Maximum, SD: Standard Deviation.

Source: Researchers' outputs using IBM SPSS 25.0 software.

\subsection{Correlation Analysis and Multicollinearity Diagnostics}

In this study, we conducted the correlation analysis for assessing the strength of the association between the independent and explanatory variables, furthermore, the correlation analysis provides an indicator of whether multicollinearity problem exist or not.

\subsubsection{Model 1, ROA}

Table (3), shows the Pearson's correlation coefficient for the first profitability model (ROA). It indicates that EQTA $(r=.612)$ and OCOI $(r=-.730)$ are strongly correlated with ROA with positive and negative signs, respectively. SECA $(r=.459)$ has a moderate positive correlation with bank's profitability, whereas both NPL $(r$ $=-.340)$ and MRKD $(r=-.106)$ show a weak negative correlation. Moreover, a weak positive correlation has been indicated by the INF exploratory variable.

Table 3. Correlation matrix for Model 1 (ROA).

\begin{tabular}{lccccccc}
\hline & ROA & EQTA & OCOI & SECA & NPL & MRKD & INF \\
\hline ROA & 1 & 0.612 & -0.730 & 0.459 & -0.340 & -0.106 & 0.153 \\
EQTA & 0.612 & 1 & -0.416 & 0.476 & -0.204 & -0.385 & -0.118 \\
OCOI & -0.73 & -0.416 & 1 & -0.303 & 0.344 & -0.134 & -0.044 \\
SECA & 0.459 & 0.476 & -0.303 & 1 & -0.053 & -0.202 & -0.239 \\
NPL & -0.34 & -0.204 & 0.344 & -0.053 & 1 & -0.106 & -0.097 \\
MRKD & -0.106 & -0.385 & -0.134 & -0.202 & -0.106 & 1 & 0.034 \\
INF & 0.153 & -0.118 & -0.044 & -0.239 & -0.097 & 0.034 & 1 \\
\hline
\end{tabular}

Source: Researchers' outputs using IBM SPSS 25.0 software.

\subsubsection{Model 1, NPM}

The correlation matrix for model 2 (NPM) is shown in table (4). The results demonstrate that EQTA $(r=-.431)$ has a moderate negative correlation with NPM while OCOI $(\mathrm{r}=-.676)$ has a strong negative relationship. A weak positive correlation with the bank's profitability has been found with variables of SECA $(r=.324)$, MRKD ( $r$ $=.096)$ and INF $(\mathrm{r}=.162)$. The results also show that a moderate negative relationship with NPM is given by $\mathrm{NPL}(\mathrm{r}=-.403)$ variable.

Table 5. Correlation matrix for Model 2 (NPM).

\begin{tabular}{lccccccc}
\hline & NPM & EQTA & OCOI & SECA & NPL & \multicolumn{2}{c}{ MRKD } \\
\hline NPM & 1 & 0.431 & -0.676 & 0.324 & -0.403 & 0.096 \\
EQTA & 0.431 & 1 & -0.416 & 0.476 & -0.204 & -0.385 \\
OCOI & -0.676 & -0.416 & 1 & -0.303 & 0.344 & -0.134 & -0.162 \\
SECA & 0.324 & 0.476 & -0.303 & 1 & -0.053 & -0.202 & -0.106 \\
NPL & -0.403 & -0.204 & 0.344 & -0.053 & -0.239 & -0.097 \\
MRKD & 0.096 & -0.385 & -0.134 & -0.202 & -0.106 & -0.097 & 0.034 \\
INF & 0.162 & -0.118 & -0.044 & -0.239 & -0.09 & 1 \\
\hline
\end{tabular}

Source: Researchers' outputs using IBM SPSS 25.0 software. 


\subsection{Collinearity Diagnostics}

Multicollinearity occurs when an independent variable is highly correlated (coefficient, $r \geq .90$ ) with one or more independent variables. It may substantially affect the variables that included in the regression estimates. Tables 3 and 4 show the correlation matrixes for the two models. They provide an evidence that there are no high correlation values between the independent variables. In fact, this suggesting that multicollinearity problem is not exist between the independent variables in this study.

Another common test for Multicollinearity is to assess the associated values of tolerance and its inverse the variance inflation factor $(V I F)$ between the independent variables. Hair et al. (2014) suggests that VIF values of even 3 to 5 consider Multicollinearity issue, while the general rule of thumb states that $V I F<10$ is acceptable. Accordingly, table 6 provides a confirmation that there is no multicollinearities problem among the explanatory variables in the study's sample, since the maximum value of $V I F=1.833$ (tolerance $=0.545$ ).

Table 6. Multicollinearity statistics

\begin{tabular}{lcc}
\hline Independent Variable & Tolerance & VIF \\
\hline EQTA & 0.545 & 1.833 \\
OCOI & 0.655 & 1.528 \\
SECA & 0.713 & 1.403 \\
NPL & 0.852 & 1.173 \\
MRKD & 0.730 & 1.370 \\
INF & 0.914 & 1.094 \\
\hline
\end{tabular}

Dependent Variables: ROA \& NPM.

Source: Researchers' outputs using IBM SPSS 25.0 software.

\subsection{Model Fit Assessment and Regression Analysis}

\subsubsection{Model Fit Assessment}

Table 7 shows the summary for regression models for ROA and NPM. The first model for ROA indicates that the correlation coefficient of $\mathrm{R}=.843(84.3 \%)$ while the second model of NPM indicates that $\mathrm{R}=.746(74.6 \%)$. This suggests existence of strong association between the profitability and explanatory variables in the two models. The coefficient of multiple determination $\left(\mathrm{R}^{2}\right)$ measures the percentage of variability in banks' profitability which explained by independent variables. The results reveal that ROA model has $\mathrm{R}^{2}=.711$ whereas NPM model gives $\mathrm{R}^{2}=0.556$. This demonstrates of $71.1 \%$ variation in ROA explained by the EQTA, OCOIC, SECA, NPL, MRKD and INF variables, whereas the same independent variables predict of $55.6 \%$ of variance in NPM. Therefore, we can see a greater the explanatory power of these regression models and subsequently they serve in the prediction of profitability of Islamic banks in Sudan. From other hand, the Adjusted $\mathrm{R}^{2}$ seen as a modified version of $\mathrm{R}^{2}$ that takes into account the sample size and the number of predictors for comparing their regression power in the models. The Adjusted $\mathrm{R}^{2}$ estimates for ROA and NPM models are Adj. $\mathrm{R}^{2}=.692$, and Adj. $\mathrm{R}^{2}=.527$, respectively.

Table 7 shows $F$-statistics that demonstrate model ROA, $F(6,93)=38.137, \mathrm{p}(.001)<.05$ and for model NPM, $F(6,93)=14.540, \mathrm{p}(.001)<.05$. Such result is deemed statistically significant of $F$-statistics and overall regression models are good fit-for-the data. Furthermore, Durbin Watson $(D-W)$ test has been applied by the researcher for assessing the autocorrelation in the residuals from the statistical regression analysis. As the rule of thumb for $D$ - $W$ statistic states that a value of or closer to 2.0, the two models provide $D$ - $W$ values of 1.897 (for ROA) and 1.798 (for NPM). Accordingly, we can estimate that there is no autocorrelation.

Table 7. ROA \& NPM models estimations

\begin{tabular}{llllllcr}
\hline & \multirow{2}{*}{ Model } & Dependent & $\mathrm{R}$ & \multirow{2}{*}{$\mathrm{R}^{2}$} & Adj. $\mathrm{R}^{2}$ & \multicolumn{3}{c}{ Change Statistics } \\
\cline { 6 - 8 } & & & & & & & \\
2 & ROA & .843 & 0.711 & 0.692 & 38.137 & Sig. $F$ Change & Durbin-Watson \\
\hline
\end{tabular}

Predictors: (Constant), EQTA, OCOI, SECA, NPL, MRKD, INF.

Source: Researchers' outputs using IBM SPSS 25.0 software. 


\subsubsection{Coefficients Correlation}

As stated in the methodology, regression analysis is applied to determine the relationship between independent and dependent variables and to identify the relative contributions of each independent variables in their relationship with the dependent variable. When the explanatory variables associated with larger regression coefficients, they make a greater contribution in the prediction value. Also, a low p-value $(<0.05)$ indicates that we can reject the null hypothesis and the predictor is likely to be valuable addition to the model. Moreover, the smaller standard error suggests more reliable prediction.

Generally, the two models of profitability (ROA and NPM) demonstrates a high level of similarity of the results in terms of explanatory variables' coefficients. The regression coefficients of EQTA, OCOI, SECA, and INF indicate that they are statistically significant to banks' profitability, whereas NPL is statistically significant to model 2 (NPM) only. The MRKD does not indicate any significant impact on both profitability measures.

Table 8 provides the estimates that can be summarized as follows:

Bank capitalization $(\mathrm{EQTA})$ : it is positively related and highly significant $(\mathrm{p}<0.0001)$ to banks profitability in both models. The results indicate that an increase of $1 \%$ of shareholders equity to bank's assets, expected to increase the return on assets by of $6.2 \%$ and the net profit margin by $3.36 \%$. Banks usually maintain significant portion from their profits to enhance the equity position and reinvestment. This result is consistent with similar other studies conducted by Bashir (2003), Hassan and Bashir (2005), Dietricha and Wanzenried (2009), Oino (2015), Aliyu and Yusof (2016), Elgadi and Yu (2018), and Jamel and Mansour (2018).

Operational cost efficiency (OCOI): the results show that the cost reduction is highly significant $(\mathrm{p}<0.001)$ in order to improve the profitability. The relationship between the cost reduction (efficiency) and the profitability improvement is inverse in the two models, as obviously expected. The decrease in the costs to revenue ratio by $1 \%$ shall lead to an increase of ROA by $4.3 \%$ and NPM by $3.17 \%$. banks are keen to manage their operational costs as it will directly impact positively to profitability. This result confirmed by the studies of Dietricha and Wanzenried (2009), Buchory (2015), Oino (2015), Rashwan and Ehab (2016), Mehta and Bhavani (2017), Elgadi and Yu (2018), and Hassan and Ahmed (2019).

Investment in short-term securities (sukuk): The results reveal that maintaining a high level of securities in form of short-term is positively and statistically significant [ROA, $(\mathrm{p}<0.05)$, NPM, $(\mathrm{p}<0.1)$ ] to profitability of banks. This indicate that an increase of $4 \%$ in bank's ROA and $2.34 \%$ in NPM found to be due to the increase of $1 \%$ in the size of short-term securities to bank's assets. Investing in short term securities by Sudanese Islamic banks not only mitigate their liquidity risk, but also contribute positively in generating addition earnings.

Quality of Credit (NPL): the quality of credit in banks comes from many factors that include a proper management of financing by maintaining low level of non-performing loan (financing) ratio. The regression analysis shows that non-performing loan is negatively correlated and insignificant to return on assets, while it has a negative relationship and significant $(\mathrm{p}<.05)$ to net profit margin. This finding reveals that bad debt is adversely affect the operational profit, since an increase of $1 \%$ in the non-performing loan / bad debt leads to a reduction in net profit margin by $80 \%$. Our result for model (2) is supported by Akhtar et al. (2011), and Tan and Floros (2012).

Market Share: the results clearly show that the industry variable of market share is insignificant to both ROA and NPM, however, it shows different coefficient signs to profitability metrics. Such result demonstrates that the relative size of the bank in term of deposits level is irrelevant to determine the profitability in banks. The more deposits seem to increase the size of assets as a form of liquidity (as well as liabilities) more than the return that expected to be generated from such deposits. Despite that, the deposits indirectly support the banks to invest in short-term securities that contribute positively to the profitability. The result is consistent with the study of Aslam et al. (2016) study and opposite to Haron and Azmi (2004).

Inflation Rate: the results reach to indicate that a positive relationship and significant impact $(\mathrm{p}<.05)$ between inflation rate and profitability of banks in Sudan. The ROA can increase by 3\% and also the NPM by $21.3 \%$ when the inflation rate increase by $1 \%$. The banks seem to have a mechanism for either adjusting their prices or rate of return (or both) due to the increase in inflation which subsequently promote the earnings capacity for those banks. Our result has matched previous studies of Bashir (2003), Haron and Azmi (2004), Tan and Floros (2012), Oino (2015), Aslam et al. (2016), and Jamel and Mansour (2018).

Finally, the results of regression analysis proved the acceptance of hypotheses H1, H2, H3, H4, H6 and rejection of $\mathrm{H} 5$. 
Table 8. Regression coefficients

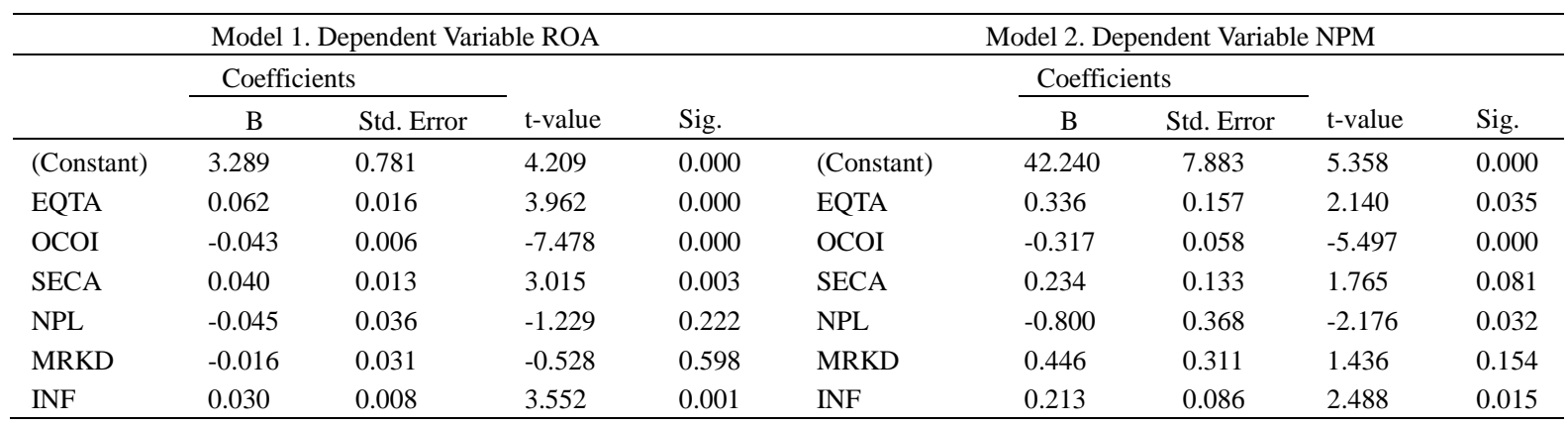

Dependent Variables: ROA \& NPM

Source: Researchers' outputs using IBM SPSS 25.0 software.

\section{Conclusions}

We have examined the effect of bank-specific and industry characteristics along with macroeconomic variable (the inflation) on the profitability of a sample of ten Islamic banks in Sudan during the period of 2009 to 2018. The study applied Pearson's correlation and multiple regression analysis to determine the relationships and degree of impact of the independent variables to two profitability models, namely return on assets and net profit margin. The results reveal that bank capitalization, operational cost efficiency, investment in short-term securities and inflation variables have a significant impact on the profitability of in Islamic banks in Sudan. While, the quality of credit loan (financing) found to be highly significant to the net profit margin. Furthermore, our results clearly indicate that the size of the bank in terms of deposits is not an essential factor in determining profitability through the banks sampled.

The study recommends that Islamic banks in Sudan are encouraged to use high tools for managing their operational costs, use the technology and skilled manpower in order to create operational efficiency that enable such banks to increase their profitability. Also, it is paramount important to develop Islamic money markets to handle a variety of Shariah securities that support the mobilization of banks funds and creating short-term investment opportunities. Furthermore, the banks have to be keen toward the quality of financing to avoid heavy losses that may severely damage the operational profitability. Obviously, the inflation - as macroeconomic variable in this study - seen as having a significant affect the Sudanese banks, especially in a country like Sudan which has high inflation rate during considerable portion of the period that covered by the study. Given that, it seems the banks are protecting their profitability status by during the inflationary position by slightly gradual increase in the non PLS income as business volume and rate of return.

This study provides significant insights for understanding the profitability determinants of Islamic banks in a general context and for Sudanese banking industry in a precise view. Which it can support the decision makers in banking industry toward the profitability matter. Furthermore, we encourage conducting further studies in the area of banks profitability and financial performance through using variety of factors (such as management and governance characteristics) and analysis models that can provide additional insights for improving the Islamic banking practices.

\section{References}

Abdullah. D. V., \& Chee. K. (2014). Islamic finance: Why it makes sense (for you) (2nd ed.). Marshall Cavendish Business, Singapore.

Akhtar, M. F., Ali. K., \& Sadaqat. S. (2011). Factors influencing the profitability of Islamic banks of Pakistan. International Research Journal of Finance and Economics, 66, 125-132.

Aliyu, S., \& Yusof, R. M. (2016). Profitability and cost efficiency of Islamic banks: A Panel analysis of some selected countries. International Journal of Economics and Financial Issues, 6(4), 1736-1743.

Aslam, M. K., \& Inamullah, I. M. (2016). Determinants Affecting the Profitability of Islamic Banks: Evidence from Pakistan. International Journal of Operations and Logistics Management, 5(2), 115-127.

Bahir. A. M. (2003). Determinants of profitability in Islamic banks: Some evidence from the middle east. Islamic Economic Studies, 11(1), 31-57.

Brown, K., Hassan, M. K., \& Skully, M. (2007). Operational efficiency and performance of Islamic banks. In Hassan M. Kabir \& Lewis Mervyn K (Eds.), Handbook of Islamic banking (pp. 96-115). USA: Edward 
Elgar Publishing Limited.

Buchory, H. A. (2015). Banking profitability: How does the credit risk and operational efficiency effect? Journal of Business and Management Sciences, 3(4), 118-123. http://doi:10.12691/jbms-3-4-3

Burger, J. (2018). The financial services sector in Sudan”, How we made it in Africa. Africa Business Insight. Retrived from https://www.howwemadeitinafrica.com/the-financial-services-sector-in-sudan/61452

Central bank of Sudan. (2011). Annual Report No:51. Retrived from https://cbos.gov.sd/en/content/annual-report-2011

Dietricha, A., \& Wanzenried, G. (2009). What determines the profitability of commercial banks? New evidence from Switzerland. 12th Conference of the Swiss Society for Financial Market Researches, Geneva.

Elgadi, E. M., \& Yu, E. P. (2018). The profitability of Islamic banking in Sudan. International Journal of Management Practice, 11(3), 233-258. https://doi.org/10.1504/IJMP.2018.092859

Hair Jr, J. F., Black, W. C., Babin, B. J., \& Anderson, R. E. (2014). Multivariate Data Analysis (7th ed.). London. UK: Pearson Education Limited.

Haron, S., \& Azmi, W. N. W. (2004). Profitability determinants of Islamic banks: A Cointegration approach. Paper presented at the Islamic Banking Conference, Union Arab Bank, Beirut, Lebnon, 5-7 December 2004. Working Paper Series 004, pp. 1-18.

Hassan, M. K., \& Bashir A. M. (2005). Determinants of Islamic banking profitability. In M. Iqbal, \& Wilson, R. (Eds.), Islamic erspectives on Wealth Creation (No. May, pp. 118-40). https://doi.org/10.3366/edinburgh/9780748621002.003.0008

Hassan, S., \& Ahmed, R. (2019). Internal determinants of Islamic bank profitability: Evidence from Bangladesh. International Journal of Economics and Financial Research, 5(7), 171-176. https://doi.org/10.32861/ijefr.57.171.176

Jamel, L., \& Mansour, S. (2018). Determinants of Tunisian banks profitability. International Journal of Business and Risk Management, 1(1), 17-27. https://doi.org/10.12691/ijbrm-1-1-3

Mehta, A., \& Bhavani, G. (2017). What determines banks' profitability? Evidence from emerging markets: The case of the UAE banking sector. Accounting and Finance Research, 6(1), 77-88. https://doi.org/10.5430/afr.v6n1p77

Muda, M., Shaharuddin, A., \& Embaya, A. (2013). Comparative analysis of profitability determinants of domestic and foreign Islamic banks in Malaysia. International Journal of Economics and Financial Issues, $3(3), 559-569$.

Oino. I. (2015). Competitiveness and determinants of bank profitability in Sub-Saharan Africa. International Journal of Economics and Finance, 7(10), 151-162. https://doi.org/10.5539/ijef.v7n10p151

Rashwan, M. H., \& Ehab, H. (2016). Comparative efficiency study between Islamic and traditional banks. Journal of Finance and Economics, 4(3), 74-87. https://doi.org/10.2139/ssrn.2801187

Shams ur Rahman, Jan, F. A., Iqbal. K., \& Ali, Z. (2012). Parameters of conventional and Islamic bank's profitability in Pakistan: Evaluation of internal factor. Research Journal of Finance and Accounting, 3(3), 11-18.

Siddiqui, A. (2008). Financial contracts, risk and performance of Islamic banking. Managerial Finance, 34(10), 680-694. https://doi.org/10.1108/03074350810891001

Tan, Y., \& Floros, C. (2012). Bank profitability and inflation: the case of China. Journal of Economic Studies, 39(6), 675-696. https://doi.org/10.1108/01443581211274610

Thomson Reuters. (2018). Islamic finance development report 2018: Building Momentum Report. Retrived from https://ceif.iba.edu.pk/pdf/Reuters-Islamic-finance-development-report2018.pdf 


\section{Appendix. List of banks in the study sample}

\begin{tabular}{|c|c|c|c|c|c|}
\hline No & Bank name & Establishement & No & Bank name & Establishmenet \\
\hline 1 & Omdurman National Bank & 1993 & 6 & Saudi Sudanese Bank & 1984 \\
\hline 2 & Blue Nile Mashreq Bank & 2003 & 7 & Tadamon Islamic Bank & 1981 \\
\hline 3 & Al Shamal Islamic Bank & 1990 & 8 & Farmer's Commercial Bank & 1999 \\
\hline 4 & Faisal Islamic Bank-Sudan & 1978 & 9 & Aljazeera Sudanese Jordanian Bank & 2006 \\
\hline 5 & Bank of Khartoum & 1913 & 10 & Investmenet Bank & 1997 \\
\hline
\end{tabular}

\section{Copyrights}

Copyright for this article is retained by the author(s), with first publication rights granted to the journal.

This is an open-access article distributed under the terms and conditions of the Creative Commons Attribution license (http://creativecommons.org/licenses/by/4.0/). 